\title{
37 Constitutionality of Precluding Arbitration Regarding National Assets
}

\author{
Mónika Ganczer
}

\subsection{Petition}

Article 38 of the Fundamental Law of Hungary provides that ' $[\mathrm{t}]$ he property of the State and of local governments shall be national assets', which shall be regulated by cardinal act. ${ }^{1}$ The Act No. CXCVI of 2011 on National Assets (hereinafter: Act on National Assets) was accordingly adopted and entered into force on 1 January 2012, containing a prohibition for those who are entitled to dispose of national assets within the borders of Hungary to stipulate in civil law contracts records to arbitration in cases of disputes. ${ }^{2}$ The Act No. LXXI of 1994 on Arbitration (hereinafter: Act on Arbitration) was amended by Act No. LXV of 2012 in conformity with this prohibition, precluding procedures before ad hoc or permanent arbitrary tribunals premised (seated) within or outside Hungary in cases where the subject-matter of the dispute is a national asset located in Hungary or any right, claim, demand pertaining thereto. ${ }^{3}$ The amending act further set forth that this rule has to be applied in procedures initiated after the entry into force; that is after 13 June 2012, of the amendment.

The petition was received by the Constitutional Court on 18 December 2012, in which Máté Szabó then Commissioner for Fundamental Rights requested the review of conformity with the Fundamental Law and the examination of conflicts with international treaties of the aforementioned provisions of the Act on National Assets and the Act on Arbitration on the basis of Articles 24(2) and 32(2) of the Act No. CLI of 2011 on the Constitutional Court. Explaining his request, the petitioner pointed out that the provisions concerned, by prohibiting the stipulation of procedures of arbitrary tribunals and precluding such proceedings in certain cases, were in conflict with Article II(1)-(2) of the European Convention on International Commercial Arbitration of 1961 (hereinafter: the Geneva Con-

\footnotetext{
* Research fellow, Hungarian Academy of Sciences, Centre for Social Sciences, Institute for Legal Studies; Assistant professor, Széchenyi István University, Deák Ferenc Faculty of Law and Political Sciences. E-mail: ganczer.monika@tk.mta.hu.

1 The Fundamental Law of Hungary, Art. 38(1)-(2).

2 Act No. CXCVI of 2011 on National Assets, Art. 17(3).

3 Act No. LXXI of 1994 on Arbitration, Art. 4, amended by Act No. LXV of 2012.
} 
vention), ${ }^{4}$ Article II(1) of the Convention on the Recognition and Enforcement of Foreign Arbitral Awards of 1958 (hereinafter: the New York Convention), ${ }^{5}$ and Article 25 of the Convention on the Settlement of Investment Disputes between States and Nationals of Other States of 1965 (hereinafter: the Washington Convention). ${ }^{6}$ The Commissioner also referred to Article Q) (2) of the Fundamental Law, of which 'Hungary shall ensure that Hungarian law be in conformity with international law' as well as to several Constitutional Court decisions.

The petitioner submitted that the objectionable provisions were incompatible with the rule of law. He claimed that the provision of the Act on National Assets was not sufficiently precise and clear, and confounded the subjective and objective sides of the legal relation sought to be regulated, thereby violating the requirement of clarity of norms. In addition, the provision of the Act on Arbitration excluded the procedure of arbitration tribunals rather than the submission to arbitration. The petitioner suggested that the paragraph could be interpreted in a way that procedures before arbitration tribunals cannot take place on the basis of arbitration clauses of agreements concluded prior to its entry into force. Thus he also claimed that the provision violated the rule of law by rendering agreements concluded before its entry into force inapplicable, and would unilaterally affect the implementation of international treaties mentioned above.

\subsection{Majority Decision}

The rapporteur of the case was Judge Péter Kovács; the decision ${ }^{7}$ was adopted by the majority of the Court, with two judges dissenting. Members of the Constitutional Court first examined the possibility of conflict between the provisions and international treaties. The Constitutional Court recalled the obvious fact that the provisions under review did not have a bearing on arbitration clauses of agreements concerning a subject matter other than national assets. Hence the Court examined the provisions of the Act on National Assets and the Act on Arbitration in a specific context. It maintained that these provisions could only affect previously concluded investment agreements concerning national assets, containing an arbitration clause, and as such could directly or indirectly affect international treaties. Consequently it analysed the possibility of conflicts with bilateral investment agreements, the Washington Convention, the Geneva Convention, and the New York Convention.

\footnotetext{
41961 European Convention on International Commercial Arbitration, 484 UNTS 349.

51958 Convention on the Recognition and Enforcement of Foreign Arbitral Awards, 330 UNTS 3.

61965 Convention on the Settlement of Investment Disputes between States and Nationals of Other States, 575 UNTS 159.

7 Decision No. 14/2013 (VI.17) of the Constitutional Court.
} 
The Constitutional Court first examined the bilateral investment treaties, and stated that Article 3(2) of the Act on Arbitration 'could, in principle, be applied to the state as an economic operator, and, by way of grammatical interpretation, even to the state as the bearer of sovereignty'. This paragraph indicates that if an act permits, the procedure of arbitration tribunals can be stipulated even if the requirement that at least one of the parties must be a person engaged in economic activities as a profession and the dispute concerns that activity is not met. The Court did not survey the almost sixty bilateral investment treaties of Hungary, but took the treaty concluded with Azerbaijan in $2007^{8}$ as a model, which was almost literally identical with other treaties of Hungary, and corresponded to the sample treaty prepared by the United Nations Conference on Trade and Development.

The need for arbitration may arise on the basis of these bilateral agreements between the state and an investor of the other state, if they cannot settle the dispute by negotiations, and the investor does not submit the dispute to the competent court of the state. In this case, the investor is entitled to submit the dispute to arbitration tribunals: to the International Centre for Settlement of Investment Disputes (ICSID) under the provisions of the Convention on the Settlement of Investment Disputes between States and Nationals of other States, or to an ad hoc arbitral tribunal established under the Arbitration Rules of the United Nations Commission on International Trade Law (UNCITRAL). The majority decision of the Court pronounced that Article 17(1) of the Act on National Assets - rights and obligations acquired lawfully and in good faith before the entry into force of the act are not affected by the act, but the extension of duration of these agreements qualifies (save for a few exceptions) as an establishment of a new legal relation - 'applies in any case to agreements (of international investment, economic nature) in force on 1 January 2012 between state organs and investors' had to be formulated 'as a constitutional requirement', 'so that no violation occur in relation to either ICSID or UNICITRAL'. The Court arrived at a similar conclusion with respect to cases, where a state was an economic partner, and as such, was in a position of an investor in relation to another state. Therefore, the Court deemed it necessary to note that the government - if it wishes to uphold the given legal relation - must ensure the renegotiation of these agreements before their expiry.

The Constitutional Court likewise analysed potential disputes between contracting states concerning the interpretation or application of these bilateral treaties, where the submission of the dispute to an arbitral tribunal might be called for. The Court 'stated as a constitutional requirement' that the Act on Arbitration and Article 17(3) of the Act on National Assets ab ovo could not be applied to the arbitral regulations of these treaties (i.e. to those, which deal with the settlement of disputes between two sovereign states).

82007 Agreement between the Republic of Hungary and the Republic of Azerbaijan for the promotion and reciprocal protection of investments, Baku, 18 May 2007. 
In spite of all that, the Court suggested the government to take action with a view to re-concluding bilateral agreements in the light of the new provisions of the Act on Arbitration and the Act on National Assets, or to withdraw from such agreements, should these conditions prove unacceptable for the partner state.

The Court then turned to examine the conflict with the Washington Convention, the Geneva Convention, and the New York Convention. It pointed out that the jurisdiction of ICSID as laid down by the Washington Convention could be influenced by states through the consent in writing required by Article 25(1), the modification of the list of constituent subdivisions or agencies of the state, or the approval of the state following the consent of the constituent subdivisions or agencies included in Article 25(3). The majority decision of the Court declared that the government must take appropriate measures in order to designate national assets as a limitation for listed organs, and to remove organs from the list that have the right to dispose of national assets. It qualified all of these measures sufficient to 'prevent the emergence of the conflict [...] even without' declaring Article 17(1) of Act on National Assets as a constitutional requirement in line with what has been mentioned above.

The Court indicated that in the case of investment agreements already concluded under the purview of the Geneva Convention, the conformity of domestic law with international law could be ensured by declaring Article 17(1) of the Act on National Assets as a constitutional requirement, thought it held possible that 'the state is bound to provide for 'legal persons of public law' to conclude arbitral agreements pro futuro'. Thus the body presumed that the exclusion of conclusion of such agreements by the provisions of the Act on National Assets and the Act on Arbitration 'may be in conflict' with the Geneva Convention. The majority opinion held that the government had to decide whether it wished to withdraw from the convention, or withdraw from and accede to it by making a restrictive declaration - essentially by making a reservation - according to Article II(2) of the convention in order to 'preclude the chance of conflict'.

As regards the New York Convention, the Court observed that the convention concerned arbitral decisions that had already been made, and existing contracts with a public international law character. Since the Act on National Assets and the Act on Arbitration did not have a bearing on the former, and the rule declared as a constitutional requirement provided guarantee for the latter, the judges could not determine a breach of the New York Convention.

The Constitutional Court subsequently carried out a joint review of the conformity of provisions concerned with the Fundamental Law by referring to the close connection, textual similarity and substantive equivalence of the analysed provisions of the two acts. The majority opinion held that the appendices of the Act on National Assets enumerating the natural, cultural and property elements that form part of national assets were sufficient 
to meet the requirement of the clarity of norms, and as such, to preclude a conflict with the rule of law under Article B) (1) of the Fundamental Law.

In the course of analysing the obligation of ensuring the conformity of domestic law with international law under Article Q) (2) of the Fundamental Law, the Court referred back to the examination of conflicts with international treaties. The constitutional requirement concerning acquired rights was sufficient to ensure conformity, and offers an adequate means to solve eventual problems. In addition, the Court underlined that 'a conflict would only occur in case certain conditions prevailed, and certainly not with respect to all affected international treaties (nor all states parties)'. Hence it did not consider necessary to annul the provisions concerned. The Constitutional Court substantiated that by having claimed to proceed under Article 46(3) of the Act on Constitutional Court and its position conformed to the established practice of 'sparing of laws'.

The Constitutional Court rejected the requests to determine the unconstitutionality and conflict with international treaties and pronounce the annulment of Article 17(3) of the Act on National Assets and Article 4 of the Act on Arbitration. The ratio decidendi of the decision was the declaration of three constitutional requirements, the first two of which was based on Articles B) (1) and Q) (2) of the Fundamental Law and consisted of the contextual interpretation and application of legal provisions.

First, the Constitutional Court referred to the joint interpretation and application of Articles 17(3) and 17(1) of the Act on National Assets as a constitutional requirement. Consequently, the provision that those who are entitled to dispose of national assets cannot stipulate records to arbitration in cases of disputes does not affect the 'rights and obligations acquired lawfully and in good faith before the entry into force of the act'.

The other constitutional requirement was the joint interpretation and application of the formula 'and in a case in which the subject-matter of the dispute is a national asset located in the territory confined by the border of Hungary under Act No. CXCVI of 2011 on national assets or any right, claim or demand pertaining thereto' in Article 4 of the Act on Arbitration and Article 55(1) b) and (2) a) on requests concerning the annulment of arbitration awards, and the aforementioned Article 17(1) of the Act on National Assets.

The Court recalled with regard to both constitutional requirements that they pertained to investment and venture agreements between Hungary and legal persons of other states, which were affected by the Act on National Assets, and were in force on 1 January 2012.

According to the third constitutional requirement, the Act on Arbitration and Article 17(3) of the Act on National Assets 'are not applicable to and do not affect' provisions of bilateral investment agreements, which envisage the establishment of arbitral tribunals for the settlement disputes between contracting parties. 


\subsection{Dissenting Opinion}

Judge Egon Dienes-Oehm attached a dissenting opinion to the decision, seconded by Judge Péter Paczolay. The dissenting opinion held that the Court should have pronounced that the provisions concerned of the Act on National Assets and the Act on Arbitration were in conflict with international treaties, and should have annulled these provisions, or should have invited the law-maker to take the necessary measures to resolve the conflict.

The dissenting opinion qualified the constitutional requirements declared in the decision as hard to follow, and held that the conflict with international treaties could not be eliminated by those requirements, as the 'fact of violation has already occurred'. Therefore, the dissenting opinion considered it a legal fact that the violation of the Geneva Convention had already occurred by the entry into force of the examined provisions of law. Since Hungary did not make a reservation to the convention, the dissenting opinion declared that the subsequent limitation by domestic law of arbitral procedure ensured by the convention qualified as a breach of an international obligation.

As regards bilateral investment agreements, the dissenting opinion recalled the cases, where the state or state organ is involved as a private legal subject with a foreign legal subject as investor. The dissenting opinion underlined that bilateral agreements contained 'the future possibility of the choice of arbitration as a method of dispute settlement', which could not be excluded by domestic law. Thus it emphasized that the constitutional requirement concerning acquired rights, as invoked by the majority decision, only protected arbitral agreements concluded on the basis of bilateral international agreements, and did not have a bearing on the general and future possibility of arbitration, e.g. the ICSID established by the Washington Convention, as ensured by those treaties. As regards the Washington Convention, the dissenting opinion - similarly to the majority decision recalled that according to Article 25(4) states parties may notify the Centre at any time of the classes of disputes, which it would not consider submitting to the jurisdiction of ICSID. However, it underlined that Hungary had not yet made such a notification concerning disputes on national assets.

In the course of analysing the conflict with international treaties, the Judges dissenting declared that the provisions examined were in conflict with the Geneva Convention and several bilateral investment agreements, and were not in conformity with other international treaties, as they revoked a possible dispute settlement method, with which the partners could count. In the latter case, the dissenting opinion referred to the Washington Convention, the New York Convention (which was not otherwise mentioned), as well as to the Geneva Convention.

The dissenting opinion recalled the fulfilment in good faith of international obligations as an element of the rule of law (Article B) (2) of the Fundamental Law), and the requirement of ensuring the conformity of domestic law with international law (Article Q) (2) of 
the Fundamental Law). The dissenting opinion held that the Constitutional Court should have 'annul[led], as a general rule, the law conflicting with international law'. The 'other possibility' mentioned by the dissenting opinion was that the Constitutional Court should have invited the law-maker to resolve the conflict under Article 42(2) of the Act on the Constitutional Court. The dissenting opinion also suggested as a possible solution the changing of domestic law: the provisions concerned may either be terminated or amended so that they become inapplicable in cases when international treaties stipulate otherwise.

\subsection{Assessment}

The decision of the Constitutional Court reviewed the alleged conflict with the Fundamental Law and international treaties of provisions held objectionable by the petitioner in a logical and well-structured manner. It duly considered possible scenarios in the conclusion of bilateral investment agreements as well as the relevant multilateral treaties. The point of departure of the decision seems to be the assumption that international treaties in the field of investment only protect already existing bilateral private investment agreements, and as such, they primarily seek to provide a safe and calculable normative environment, including the possibility of having recourse to dispute settlement mechanisms, for investors, who conclude private law contracts with the state or organs of the state.

However, prior to the adoption of the decision, a rather different position was articulated in the legal literature, which holds that obligations arising from investment protection treaties have a much wider scope, and offer the possibility of recourse to arbitration as a dispute settlement mechanism to future investors, as well. ${ }^{9}$ In other words, these treaties likewise formulate demands with regard to the contents of private law contracts that will only be concluded at a later date, and actually seek to secure that states mutually assist their respective investors by laying down the essential conditions of future investments.

In the case of bilateral investment agreements the obligation pertains to investments established by private law contracts. The state is obliged to conclude contracts with investors with very specific conditions rather than to generally accept investments for the future. The obligation, therefore, pertains to the contents of future contracts, not the conclusion of such contracts. At present, the Hungarian state cannot conclude private law investment contracts concerning its national assets. If the state concluded such a contract, it would not be able to preclude the stipulation of arbitration on account of its international obligations, but the stipulation of arbitration would contradict its domestic law.

9 L. Kecskés and P. Tilk, 'A választottbírósági kikötés hazai jog szerinti tilalmának Alaptörvénybe, illetve nemzetközi jogba ütközése' [The incompatibility with the Fundamental Law as well as international law of the prohibition of the stipulation of arbitration under domestic law] 12(2) Európai Jog (2012), p. 18. 
The Constitutional Court examined three scenarios with respect to bilateral investment protection agreements, the first two of which - namely, the relationship of the state and the investor of another state and that of the state and another state as investor - may be assessed together due to the similarities of relevant findings. In both cases, the Court pronounced the inviolability of acquired rights as a constitutional requirement. This requirement indeed protects private law contracts that were in effect as of 1 January 2012, which rules out the possibility of a conflict with international treaties.

The Court only spelled out the objective of the constitutional requirement at issue: to prevent violations in the relations of both ICSID and UNICITRAL. The basis of the constitutional requirement, however, remained in obscurity, though it would have greatly reinforced the adequacy of its invocation. First, the Court could have referred to Article B) (1) of the Fundamental Law, and recalled that the protection of acquired rights originates from the rule of law, and can also be deduced from the prohibition of retroactive effect. Second, with regard to Article 17(1) and (3) of the Act on National Assets, the joint interpretation and application of the act offers an additional basis, which lies in the act, and does not call for its pronunciation as a constitutional requirement.

The Constitutional Court rightly observed that the provisions of the Act on Arbitration and the Act on National Assets are not applicable to the third scenario concerning bilateral agreements, that is, when the necessity of arbitration materializes in a dispute between states parties. This conclusion may too be deduced from the contents of these provisions, and as such, its pronouncement as a constitutional requirement does by no means produce, but merely reinforces that outcome.

The Constitutional Court, therefore, did not consider the provisions concerned to be in conflict with bilateral international agreements, still it called upon the government to re-conclude such agreements in the light of these provisions before their expiry, or, if the other contracting party does not concur, to withdraw from such agreements. At this point one should recall the peculiar temporal effect of bilateral investment protection agreements. For example, the agreement concluded with Azerbaijan remains in force for a ten-year period, afterwards automatically prolonged for consecutive ten-years periods, until one of the parties notifies the other party in writing about the termination of the agreement at least one year before the end of the actual ten-year period. Another noticeable provision is that in respect of investments made prior to the termination of the agreement; the provisions of the agreement shall continue to be effective for a period of ten years from the date of termination.

The Washington Convention envisages the establishment of the ICSID, and prescribes strict requirements for its jurisdiction. I agree with the statement of the Constitutional Court that a conflict between domestic law and international law may not emerge due to 
the fact that consent is required for its jurisdiction, ${ }^{10}$ and due to the notifications under Article 25(4). Since states are entitled rather than obliged to make notifications ('may [...] notify'), the obligation of the government to take measures as mentioned in the decision may at best be deemed a recommendation. Nevertheless, a notification should be made in order to inform other state parties.

As regards the Geneva Convention, we may recall, similarly to the Court itself, the observations of the Constitutional Court concerning bilateral investment agreements. It should be added that the possible interpretation mentioned by the Court in fact covers the meaning of the provision in the sphere of international law. ${ }^{11}$ If the chance of a conflict truly exists, the recommendation of the Court to withdraw from the convention or later accede thereto with a reservation seems problematic. The convention was promulgated by a law-decree, which shares the position of acts in the domestic hierarchy of sources of law, the eventual conflict of which is not unequivocally regulated by the Act on the Constitutional Court. The formula 'according to the Fundamental Law, shall not be in conflict' in that act offers little guidance here. ${ }^{12}$ Hence the Constitutional Court is free to decide whether it applies Article 42(1) or (2) of the Act on the Constitutional Court, and to suggest the annulation of the law in whole or in part, or to invite the government or the law-maker to take the necessary measures with a view to resolving the conflict. ${ }^{13}$ The latter can equally mean the adjustment of domestic law to international law or the amendment or termination of the international treaty, as appropriate. It should be emphasized that both the previous regulation and the practice of the Court prescribed ${ }^{14}$ or favoured ${ }^{15}$ the annulation of the domestic enactment or its adjustment to international standards - solutions that may too offer guidance in our case.

The analysis and conclusion focusing on the New York Convention is adequate, and confirms that at this point a conflict with an international treaty does not occur either.

10 See J. Katona, 'Néhány megjegyzés a nemzeti vagyont érintő választottbírósági kikötés tilalma és a beruházásvédelem nemzetközi jogi szabályainak konfliktusáról' [Some remarks on the conflict of the prohibition of the stipulation of arbitration concerning national assets and the international legal rules of investment protection], 12(6) Európai Jog (2012), p. 25.

11 Decision No. 30/1998 (VI.25) of the Constitutional Court; Decision No. 54/2004 (XII.13) of the Constitutional Court, dissenting opinion of Judge István Kukorelli; G. Sulyok, 'A nemzetközi jog és a belső jog viszonyának alaptörvényi szabályozása' [The relationship of international law and domestic law under the Fundamental Law], IV(1) Jog - Állam - Politika (2012), p. 33.

12 For the constitutional prohibitions of conflicts see Sulyok, 2012, p. 39, note 94.

13 Cf. L. Blutman, 'A nemzetközi jog hatásai az alkotmánybírósági eljárásokban' [The effects of international law in constitutional court procedures], (4) Jogelméleti Szemle (2013), p. 21, note 52; L. Blutman, 'A nemzetközi jog érvényesülése a magyar belső jogban: joghatások' [The enforcement of international law in Hungarian domestic law: legal effects], in L. Blutman et al. (Eds.), A nemzetközi jog hatása a magyar joggyakorlatra [The effect of international law on Hungarian legal practice], HVG-ORAC, Budapest, 2014, p. 153.

14 Act No. XXXII of 1989 on the Constitutional Court, Art. 45(1).

15 Decision No. 30/1990 (XII.15) of the Constitutional Court, Decision No. 15/2004 (V.14) of the Constitutional Court. 
Remarkably, the Constitutional Court did not react to each and every issue raised in the petition concerning the alleged inconformity with Article B) (1) of the Fundamental Law. The objections regarding the clarity of the Act on National Assets were dismissed with reference to the annexes of the act, but failed to refute the statement that the Act on Arbitration prohibits the stipulation of the procedure of arbitration tribunals rather than arbitration itself.

The Court extended the review of conformity with the Fundamental Law in the light of its Article Q) (2), which sets forth the obligation to ensure harmony between domestic law and international law. It should be noted as a minor correction that the absence of harmony may be determined even if it does not involve all relevant international treaties and states parties, a single conflict between norms is totally sufficient for that. The principle of rule of law as declared by Article B (1) may likewise be brought to mind here, for it also covers 'conformity with international legal obligations assumed by the Hungarian state', ${ }^{16}$ or in other words, the fulfilment of international obligations in good faith. ${ }^{17}$ For that reason, the termination of international obligations as a means of ensuring harmony undermines not only the international legal order, but also the rule of law.

The importance of the decision is clearly demonstrated by the academic debate that commenced in the wake of the entry into force of the provisions concerned over their conformity with the Fundamental Law and international treaties. ${ }^{18}$ Nevertheless, its practical effects remain to be seen, and are greatly dependent on the measures the government would take in the field of investment protection.

16 Decision No. 7/2005 (III.31) of the Constitutional Court.

17 T. Molnár, A nemzetközi jogi eredetü normák beépülése a magyar jogrendszerbe [The incorporation of norms originating from international law into the Hungarian legal system], Dialóg Campus Kiadó - Dóm Kiadó, Budapest - Pécs 2013, p. 221.

18 Kecskés and Tilk, 2012, p. 18; Katona, 2012, p. 25. 